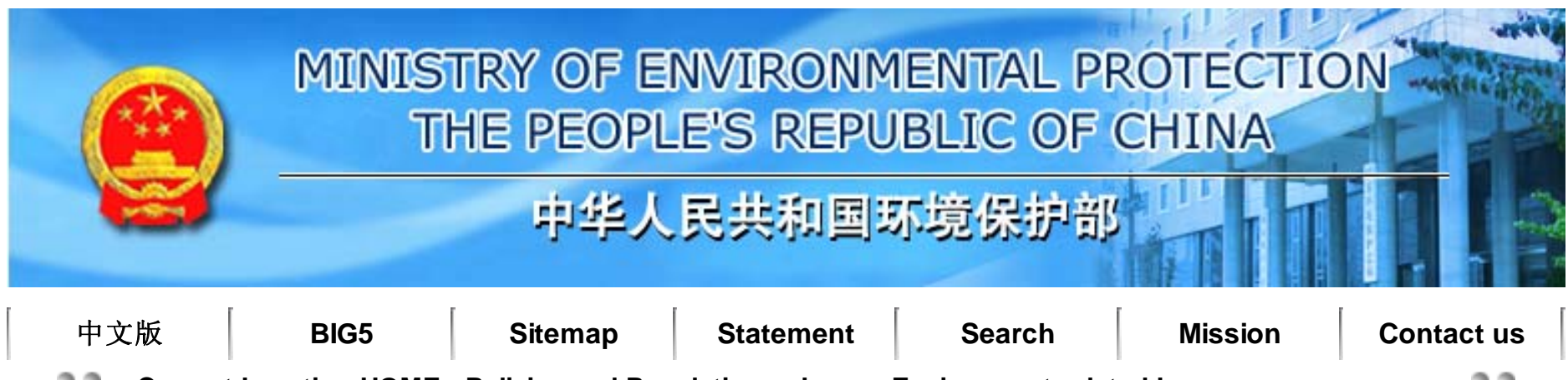

Current Location:HOME->Policies and Regulations->Laws->Environment-related Laws

\title{
Law of the People's Republic of China on Desert Prevention and Transformation
}

2001-08-31

Article type: Redistributed

(Adopted at the 23rd meeting of the Standing Committee of the Ninth National People's Congress of the People's Republic of China on Aug.31, 2001)

\section{CHAPTER I GENERAL PROVISIONS}

Article 1 This Law was formulated in order to prevent land desertification, to transform desertified land, to protect the safety of environment and to promote the sustainable development of economy and society.

Article 2 The activities of prevention of land desertification, transformation of desertified land, development and utilization of desertified land within the territory of the People's Republic of China must abide by this Law.

Land desertification refers to the encroachment of natural desert and the process in which the vegetation on sandy land is damaged and the sandy soil is exposed due to climate changes and human activities.

Land desertification referred to in this Law means the encroachment of natural desert and the process in which the vegetation and coverings on sandy land are damaged, quicksand is formed and the sand soil is exposed due to unreasonable human activities.

Desertified land referred to in this Law means the land that has already been desertified and the land that is obviously going to be desertified. The specific scope shall be clarified by the planning on national desert prevention and transformation approved by the State Council.

Article 3 Desert prevention and transformation shall follow the following principles:

1) planning desert prevention and transformation uniformly, adjusting it according to the circumstances, carrying 
it out step by step, and insisting on the combination of regional and key prevention and transformation;

2) giving priority to prevention, combining prevention with transformation, and transforming desertified land in a comprehensive way;

3) combining the protection and restoring of vegetation with the reasonable utilization of natural resources;

4) following environmental rules and relying on technological advancement;

5) combining the improvement of environment with helping peasants and herdsmen get out of poverty and become rich;

6) combining the state support with local self-reliance, combining the government organization with public participation, and encouraging units and individuals to contract for desert prevention and transformation; and;

7) protecting the lawful rights and interests of the persons engaged in the sand prevention and transformation.

Article 4 The State Council and the local people's governments at the county level or above of the places where the desertified lands are located shall bring the desert prevention and transformation into the plans of the development of national economy and society, and shall protect and support the carrying out of desert prevention and transformation.

The local people's governments at all levels of the places where the desertified lands are located shall take effective measures to prevent land desertification, to transform the desertified land and to protect and improve the environmental quality of their respective administrative areas.\&nbsp;

At the places where the desertified lands are located, the state shall establish examination, award and punishment system of government administrative leaders on their responsibilities of accomplishing sand prevention and transformation objectives within their office terms. The local people's governments at the county level or above of the places where the desertified lands are located shall report the goings of sand prevention and transformation to the people's congresses and their standing committees at the same level.

Article 5 Under the leadership of the State Council, the administrative department in charge of forestry of the State Council shall be responsible for the organization, coordination and direction of the desert prevention and transformation of the whole country. 
The administrative departments in charge of forestry, agriculture, irrigation works, land, environment protection, etc, and the organ in charge of weather shall, according to the responsibilities provided by relevant laws and the division of responsibilities determined by the State Council, perform their respective duties, coordinate with each other closely and jointly do a good job in desert prevention and transformation.

The local people's governments at the county level or above shall organize and lead the relevant departments under them to perform their respective duties according to the division of duties, coordinate with each other closely and do a good job of desert prevention and transformation of their respective administrative areas.

Article 6 The units and individuals using land shall bear the obligation to prevent that land from desertification.

The units and individuals using the land that has already been desertified shall bear the obligation to transform that desertified land.

Article 7 The state shall support the scientific research and technological spreading of desert prevention and transformation, bring the role of scientific research departments and organs into play in desert prevention and transformation, train special technological personnel of desert prevention and transformation and improve the level of scientific technologies of desert prevention and transformation.

The state supports international cooperation in desert prevention and transformation.

Article 8 The units and individuals that make notable achievements in desert prevention and transformation shall be honored and awarded by the people's governments; those that make prominent contributions to protect and improve environment quality shall be given ample awards.

Article 9 The people's governments at all levels of the places where the desertified lands are located shall organize the relevant departments to carry out publicizing and education on knowledge of desert prevention and transformation, increase the sense of desert prevention and transformation of the citizens and improve the capacities of desert prevention and transformation of the citizens.

\section{CHAPTER II PLANNING OF DESERT PREVENTION AND TRANSFORMATION}

Article 10 Desert prevention and transformation shall adopt uniform planning. The activities of desert prevention and transformation, and the activities of development and utilization within the range of desertified land must abide by the planning on desert prevention and transformation.

The planning on desert prevention and transformation shall make definite provisions on the time limits, steps, 
measures, etc, for preventing the tendency of land desertification expansion and for gradually reducing the desertified land, and shall bring the specific implementation schemes into the five-year plans and annual plans of national economic and social development.

Article 11 The administrative department in charge of forestry of the State Council shall, jointly with the relevant departments of agriculture, irritation works, land, environment protection, etc, of the State Council, draw up the planning of desert prevention and transformation of the whole country, which shall be carried out upon the approval of the State Council.

The people's governments of provinces, autonomous regions, and municipalities directly under the Central Government shall, according to the planning of desert prevention and transformation of the whole country, draw up the planning of desert prevention and transformation of their respective administrative areas, which shall be carried out upon the approval of the State Council or of the relevant departments appointed by the State Council.

The people's governments of the cities, counties of the places where the desertified lands are located shall, according to the planning of desert prevention and transformation of the people's governments at the higher level, organize the formulation of the planning of desert prevention and transformation of their respective administrative areas, which shall be carried out upon the approval of the people's government at the higher level.

To amend the planning of desert prevention and transformation, the approval of the original approving department must be obtained; no unit or individual may change the planning of desert prevention and transformation without approval.

Article 12 The formulation of planning of desert prevention and transformation shall adopt classified protection, comprehensive transformation and reasonable utilization of the desertified land according to the natural conditions such as geological location of the desertified land, land types, vegetation conditions, climate and water resource conditions, land desertification degrees, etc, and the environmental and economic functions the desertified land plays.

The connected patches of desertified land that are not suitable for development and utilization because there are no conditions for transformation in the planned term and because of the needs of environment protection shall be planned as the sealed conservation area of desertified land and shall adopt sealed protection. The range of the sealed conservation area of desertified land shall be determined by the planning of desert prevention and transformation of the whole country and that of the provinces, autonomous regions and municipalities directly under the Central Government.

Article 13 The planning of desert prevention and transformation shall be linked up with the overall planning of land 
use; and the use of desertified land prescribed in the planning of desert prevention and transformation shall be in accordance with the overall planning of land use of the people's government at the corresponding level.

\section{CHAPTER III PREVENTION OF LAND DESERTIFICATION}

Article 14 The administrative department in charge of forestry of the State Council shall organize other relevant administrative departments in charge to monitor, count up and analyze the circumstances of land desertification of the whole country and shall publicize the monitoring results regularly.

The administrative departments in charge of forestry or other relevant departments of the local people's governments at the county level or above shall, according to the technological rules of land desertification monitoring, monitor the desertified land and report the monitoring results to the people's government at the same level and the administrative departments in charge of forestry or other relevant departments at the higher level.

Article 15 The administrative departments in charge of forestry or other relevant administrative departments of the local people's governments at the county level or above shall report to the people's governments at the same levels when they find the land are being desertified or the degree of land desertification increases during the process of monitoring land desertification. The people's governments that receive the reports shall instruct the relevant administrative departments in charge to stop the acts that cause the land desertification and take effective measures to transform it.

The departments in charge of meteorology at all levels shall organize the monitoring and forecast of the drought weather and sandstorm weather, and shall report to the local people's governments when finding the symptoms of drought or sandstorm weather. The people's governments that receive the reports shall take prevention measures and make disaster forecasts when necessary, and shall organize the relevant departments of forestry, agriculture (livestock farming), etc, to take emergency measures to avoid or reduce the sandstorm damages.

Article 16 The local people's governments at the county level or above of the places where the desertified lands are located shall, according to the planning of desert prevention and transformation, line out a certain proportion of land to build anti-wind and sand-fixation forest nets, forest zones, and to plant perennial bushes and herbage plants. The administrative departments in charge of forestry shall be responsible for determining the standards and specific tasks of the surviving rate and preserving rate of the tree and forest planting, and shall organize the implementation in the lands patch by patch, determine the responsibilities and insure the completion.

Except the felling for fostering and renewing, no felling of trees may be approved on the anti-wind and sand-fixation forest nets and forest zones. Before felling trees in the anti-wind and sand-fixation forest nets and forest zones for fostering and renewing, succeeding forest nets and forest zones must be formed near them. 
No felling shall be approved on the anti-wind and sand fixation forest nets and forest zones at the places where it is difficult to renew forests.

Article 17 It is prohibited to chop and dig bushes, medical materials and other sand-fixation plants on the deserted land.

The people's governments at the county level of the places where the deserted lands are located shall formulate vegetation management and protection system to rigorously protect the vegetation, and shall establish management and protection organizations at townships (towns), villages and fixing management and protection personnel according to needs.

Various kinds of land underwriting contracts shall include the contents of responsibilities fro vegetation protection within the range of deserted land.

Article 18 The local people's governments at all levels of the grassland regions shall strengthen the management and improvement of the grasslands, the administrative departments of agriculture (livestock farming) shall be responsible for the direction and organization of the peasants and herdsmen to build man-made meadows, to control the livestock carrying capacity, to adjust the livestock structure, to improve the livestock categories, to spread fence farming of livestock and shifting meadow herding, to eliminate rat pests and insect pests on the grasslands, to protect grassland vegetation and to prevent the grasslands from degeneration and desertification.

The grasslands shall adopt the system of determining livestock carrying capacity by grass output. The administrative departments in charge of agriculture (livestock farming) shall be responsible for formulating the standards for and the relevant provisions on the livestock carrying capacity, and shall organize the implementation level by level, define the responsibilities and insure the completion.

Article 19 The administrative departments in charge of irritation works of the local people's governments at the county level or above of the places where the desertified lands are located shall strengthen the uniform arrangements and management of the drainage areas water resources and regional water resources, the water needed for the vegetation protection of the whole drainage areas and regions must be taken into consideration when drawing up the planning of the development and utilization of the water resources of the drainage areas and regions and the water supplying plans, thus to prevent vegetation damages and land desertification caused by the excess development and utilization of groundwater and the upriver water resources. Those planning and plans must be strictly carried out after being approved.

The local people's governments at all levels of the places where the desertified lands are located shall save 
water, develop water-saving agriculture and livestock farming and other industries.

Article 20 The people's governments at the county level or above of the places where the desertified lands are located may not approve the cultivation of the edging zones of deserts and the forests and grasslands; if they have already cultivated the lands and harmful effects have been done to the environment, the cultivated lands shall be restored to forests and grasslands in a planned and organized way.

Article 21 When undertaking development and construction within the range of the desertified land, one must make environmental valuation on the effects that project may generate to the environment of the land and the relevant regions in advance, and shall submit the report on environmental effects according to law; the contents of the report on environmental effects shall include contents relating to desert prevention and transformation.

Article 22 All vegetation damaging activities shall be prohibited within the range of the sealed conservation areas of desertified land.

It is prohibited to settle incomers within the range of the sealed conservation areas of the desertified land. The local people's governments at the county level or above shall organize the peasants and herdsmen in the range of sealed conservation areas of desertified land to move out in a planned way and shall settle them down appropriately. The production and living of the peasants and herdsmen that haven't moved out of the sealed conservation areas of desertified land shall be appropriately arranged by the departments in charge of the sealed conservation areas of desertified land.

No construction of railway, highway, etc, may be conducted within the range of the sealed conservation areas of the desertified land without the approval of the State Council or the departments appointed by the State Council.

\section{CHAPTER IV TRANSFORMATION OF DESERTIFIED LAND}

Article 23 The local people's governments at all levels of the places where the desertified lands are located shall, according to the planning of desert prevention and transformation, organize the relevant departments, units and individuals to take the measures such as forestation and grass-growing by human power, forestation and grassgrowing by plane insemination, blocking desert for forest and grass fostering, reasonable allocation of water for environmental use, etc, according to the circumstances, and to restore and increase vegetation and to transform the land that have already been desertified.

Article 24 The state encourages units and individuals, on the premise of freewill, to carry out public desert transforming activities by contributing money or by other means.

The administrative departments of forestry or other relevant administrative departments of the local people's 
governments at the county level or above shall provide sites for the transformation and free technological direction for the public desert transforming activities.

The units and individuals engaged in public desert transformation shall carry out the transformation according to the technological requirements of the administrative departments in charge of forestry and other relevant administrative departments of the local people's governments at the county level or above, and may entrust others to manage and protect the forests and grasses they have planted or hand them over to the relevant administrative departments in charge of the local people's governments for management and protection.

Article 25 The owners of land use right who use the state-owned lands that have already been desertified and the contractor of the rural collectivity-owned lands must take transforming measures and improve the land quality; those that do have no capacity to complete the transforming tasks may entrust others to conduct the transformation or cooperate with others to transform the land. Those entrust others or cooperate with others to transform the land shall sign agreements and clarify the rights and obligations of the parties.

The local people's governments at all levels of the places where the desertified lands are located, the relevant administrative departments in charge and the technology spreading units shall provide technological direction for the desert transforming activities of the owners of land use right and the contractors.

The owners of land use right and contractors who adopting the measure such as restoring cultivated lands to forests and grasses, planting trees and grasses or blocking desert for fostering may enjoy the preferential policy provided by the people's governments according to the relevant provisions of the state.

Article 26 If any unit or individual who doesn't have the land ownership or land use right wishes to engage in profit-making desert transforming activities, he shall sign agreements with the owner of the land or the owner of land use right in advance to obtain the land use right according to law.

Before the transforming activities begin, the units or individuals shall apply for transformation to the administrative departments in charge of forestry of the local people's governments at the county level or above or to other administrative departments in charge appointed by the local people's governments at the county level or above, and shall submit the following documents together with the application:

1) legal proving documents of the ownership of the land under transformation and the transforming agreement;

2) transforming schemes that comply with the planning of desert prevention and transforming; and\&nbsp; 
3) proving documents of the funds needed by the transformation.

Article 27 The transforming schemes referred to in item 2) of the second paragraph of Article 26 shall include the following contents:

1) limits of the transforming range;

2) grading transforming objectives and transforming terms;

3) main transforming measures;

4) water sources and water use quotas approved by the local administrative departments in charge of irrigation;

5) land use after transformation and the measures for vegetation management and protection; and\&nbsp;

6) other matters needed to be indicated.

Article 28 The units and individuals engaged in profit-making desert transformation must transform the land according to the transforming schemes.

The state protects the lawful rights and interests of the persons transforming desertified land. No other unit or individual may undertake activities of transformation or development and utilization in the transforming range under the land ownership obtained by the persons transforming the land without their approval.

Article 29 After completing the transforming tasks, the persons transforming the land shall apply for check before acceptance to the administrative departments in-charge of the local people's governments at the county level or above that accepted the transforming application. For those that pass the check before acceptance, the administrative departments in-charge that accepted the transforming application shall issue certificates of qualified transformation; and for those failed to pass the check before acceptance, the persons transforming the land shall continue with their transformation.

Article 30 The two sides of the railways, highways, rivers and canals, and the areas around the towns, villages, factories and mines, and reservoirs within the range of the lands that have already been desertified shall adopt the responsibility system of unit transformation, the local people's governments at the county level or above shall deliver the transformation responsibility letter, and the responsible units shall answer for the organizing of forest and grass planting or take other transforming measures.

Article 31 The local people's governments at all levels of the places where the desertified lands are located may 
organize the local rural collectivity economic organizations and their members, on the premise of freewill, to make centralized transformation to the desertified land. The funds and labor devoted by the rural collectivity economic organizations and their members may be converted into the shares, capital of the transforming projects, or may be compensated by other means.

\section{CHAPTER V GUARANTEE MEASURES}

Article 32 The State Council and the local people's governments at all levels of the places where the desertified lands are located shall arrange funds from the financial budget of their respective levels through project budget according to the planning of desert prevention and transformation, those funds shall be used in the desert prevention and transformation projects determined by the people's governments at the corresponding level. In the arrangement of the projects of poverty-relief, agriculture, irrigation works, mineral resources, energy, comprehensive agriculture development, etc, several sub-projects of sand prevention and transformation shall be established according to the specific circumstances.

Article 33 The State Council and the people's governments of provinces, autonomous regions, and municipalities directly under the Central Government shall formulate preferential polices to encourage and support units and individuals to prevent and transform desert.

The local people's governments at the county level or above shall grant policy preferences such as fund subsidies, financial discounts and reduction and exemption of tax to the units and individuals engaged in desert prevention and transformation.

For the units and individuals that invest in preventing and transforming deserts, all kinds of taxes shall be exempted at the phase of investing; relevant taxes may be exempted or reduced after some profits have been made.

Article 34 Those that use desertified state-owned lands to conduct desert prevention and transformation may enjoy the land use right for no more than 70 years upon the approval of the people's governments at the county level or above. The specific time limit and the management measures shall be prescribed by the State Council.

Those that use desertified collectivity-owned lands to conduct desert prevention and transformation shall sign land underwriting contracts. The specific contracting terms and other rights and obligations of the parties shall be agreed upon in the land underwriting contract by both parties to the contract. The people's governments at the county level or above shall issue the certificates of land use right to the persons transforming the land according to the land underwriting contract, thus to protect the land use right of the persons transforming the collectivity-owned desertified lands. 
Article 35 Where the transformed lands are approved to be lined out as natural conservation areas or sealed conservation areas of desertified land because of special requirements of environmental protection, the approving departments shall give reasonable compensation to the persons transforming the land.\&nbsp;

Article 36 The state shall organize the establishment of key scientific and research projects and the demonstration and spreading projects of desert prevention and transformation, and shall grant policy preferences such as fund subsidies, reduction and exemption of tax, etc, to the scientific research and technological spreading in the aspects of desert prevention and transformation, energy in sandy regions, economic crops growing in sand, water-saving irrigation, prevention of plain degeneration, dry farming in sandy land, etc.

Article 37 No unit or individual may withhold or embezzle the funds for desert prevention and transformation.

The auditing departments of the people's governments at the county level or above shall carry out auditing supervision over the use of the funds for desert prevention and transformation.

\section{CHAPTER VI LEGAL RESPONSIBILITIES}

Article 38 For those, in violation of the provisions of the first paragraph of Article 22 of this Law, conducting vegetation damaging activities within the range of the sealed conservation areas of desertified lands, the administrative departments in charge of forestry, agriculture (livestock farming) of the local people's governments at the county level or above shall, according to their respective duties, order them to stop their illegal acts; the illegal gains shall be confiscated if there are any; and the criminal responsibilities shall be investigated into if a crime is constituted.

Article 39 Where the owners of the land use right of state-owned lands and the contractors of rural collectivity-owned lands, in violation of the first paragraph of Article 25 of this Law, haven't taken measures for desert prevention and transformation and thus caused serious land desertification, the administrative departments in charge of forestry, agriculture (livestock farming) of the local people's governments at the county level or above shall, according to their respective duties, order them to transform the lands within a limit of time, and where serious desertification of state-owned lands is caused, the people's governments at the county level or above may withdraw the land use right of state-owned lands.

Article 40 For those, in violation of the provisions of this Law, conducting profit-making activities and thus causing the aggravation of land desertification, the administrative departments of the local people's governments at the county level or above that are responsible for accepting the application for profit-making desert transformation shall order them to stop their illegal acts, and may impose on them a fine of more than 5,000 Yuan and less than 50,000 Yuan per hectare at the same time. 
Article 41 For those, in violation of the provisions of the first paragraph of Article 28 of this Law, that haven't transformed desert according to the transforming schemes, or for those, in violation of the provisions of Article 29 of this Law, that failed to pass the check before acceptance and don't continue to transform the desert according to the requirements, the administrative departments of the local people's governments at the county level or above that are responsible for accepting the application for profit-making desert transformation shall order them to stop their illegal acts and make corrections within a time limit, and may impose on them a fine of more than 1 time and less than 3 times of the transforming expenses.

Article 42 For those, in violation of the provisions of the second paragraph of Article 28 of this Law, conducting transformation or development and utilization activities within the transforming range of others, the administrative departments of the local people's governments at the county level or above that are responsible for accepting the application for profit-making desert transformation shall order them to stop their illegal acts; those that caused losses to the persons transforming the land shall compensate for the losses.

Article 43 Under any of the following circumstances, the directly responsible personnel in-charge and other directly responsible personnel shall be given administrative punishments by their units, supervision departments or the administrative departments in charge at the higher level according to law:

1) in violation of the provisions of the first paragraph of Article 15 of this Law, having not reported after finding the land is being desertified or the desertification degree has increased, or having not order the relevant administrative departments in charge to take measures after receiving the reports;

2) in violation of the provisions of the second, third paragraphs of Article 16 of this Law, approving the felling of trees in the anti-wind and sand-fixation forest nets and forest zones;

3) in violation of the second, third paragraphs of Article 20 of this Law, approving the cultivation of the edging areas of deserts and forests, grasslands;

4) in violation of the provisions of the second paragraph of Article 22 of this Law, settling incomers in the range of sealed conservation areas of desertified lands; and\&nbsp;

5) in violation of the provisions of Article 22 of this Law, conducting construction activities such as building railways, highways, etc, in the range of sealed conservation zones of desertified lands without approval.

Article 44 For the directly responsible personnel in-charge and other directly responsible personnel who, in violation of the provisions of the first paragraph of Article 37 of this Law, withheld or embezzled the funds for 
desert prevention and transformation, the supervision departments or the administrative departments in charge at the higher level shall give administrative punishments according to law; and the criminal responsibilities shall be investigated into if a crime is constituted.

Article 45 If the supervision and management personnel of desert prevention and transformation abuse their powers, neglect their duties, practice favoritism and irregularities and thus a crime is constituted, the criminal responsibilities shall be investigated into according to law.

\section{CHAPTER VII SUPPLEMENTARY PROVISIONS}

Article 46 The relevant laws referred to in the second paragraph of Article 5 of this Law mean the Law of the People's Republic of China of Forest, the Law of the People's Republic of China on Grassland, the Law of the People's Republic of China on Conservation of Water and Soil, the Law of the People's Republic of China on Land Administration, the Law of the People's Republic of China on Environment Protection and the Law of the People's Republic of China on Meteorology.

Article 47 This Law shall come into force on Jan.1, 2002.

Source:

【 Big Medium-sized Small 】

【Print】【Close】

Sponsored by MEP, Address: No.115 Xizhimennei Nanxiaojie, Beijing (100035)

Telephone Numbers for Administrative Offices 